\title{
PROFIL GENOTIPBENIH UDANG WINDU Penaeus monodon HASIL SELEKSI DENGAN KARAKTER TOLERAN TERHADAP INFEKSI WHITE SPOT SYNDROME VIRUS
}

\author{
Haryanti, Fahrudin, Ida Komang Wardana, Sari Budi Moria, \\ Gusti Ngurah Permana, dan Ketut Mahardika \\ Balai Besar Riset Perikanan Budidaya Laut \\ PO Box 140 Singaraja 81101 - Bali \\ E-mail: haryanti@indosat.net.id
}

(Naskah diterima: 13 Juli 2011; Disetujui publikasi: 28 Oktober 2011)

\begin{abstract}
ABSTRAK
Upaya seleksi pada benih udang windu dengan mengutamakan karakter toleran terhadap WSSV menjadi prioritas, agar diperoleh calon induk udang windu dengan karakter genotip yang lebih baik. Tujuan riset adalah mendapatkan profil genotip benih udang windu hasil seleksi dengan karakter toleran terhadap WSSV. Metode untuk mendapatkan benih udang terseleksi, diawali melalui pembenihan dengan menggunakan induk udang windu berasal dari alam (F-0), mengaplikasikan probiotik dalam pemeliharaan larva, biosecurity dan pemantauan infeksi virus. Uji tantang virus WSSV (LD- 50) dilakukan dengan perendaman dan pemberian pakan (oral). Hasil yang diperoleh menunjukkan bahwa benih udang F- 1 memberikan keragaan fenotip yang bervariasi (ukuran besar, sedang dan kecil). Benih udang F- 1 berukuran besar, diperoleh $20,18 \% 35,04 \%$ sedangkan ukuran sedang dan kecil masing- masing sebesar 43,28\% $0,49 \%$ dan $9,47 \% 21,66 \%$ dari populasi benih udang yang dihasilkan. Keragaan genotip benih F- 1 menunjukkan keragaman genetik yang berbeda. Nilai heterozigositas pada benih F- 1 pada udang dengan ukuran besar adalah 0,51, sedangkan ukuran sedang dan kecil masing-masing 0,45 dan 0,22. Hasil uji tantang dengan WSSV melalui perendaman maupun pemberian pakan (oral) terlihat ada perbedaan toleransi pada benih udang F-1. Dengan LD- 50 menunjukkan bahwa pada udang ukuran kecil, mortalitas terjadi dalam waktu 48 jam (oral). Sementara, pada udang ukuran besar dan sedang, mengalami mortalitas dalam waktu 72 jam. Profil genotip benih udang yang toleran terhadap infeksi WSSV mengekspresikan pola gen yang lebih bervariasi
\end{abstract}

KATA KUNCI: Penaeus monodon, seleksi, toleran, infeksi WSSV

ABSTRACT: Genotype profile of black tiger shrimp Penaeus monodon produced from selective breeding with tolerance traits to WSSV infection. By: Haryanti, Fahrudin, Ida Komang Wardana, Sari Budi Moria, Gusti Ngurah Permana, and Ketut Mahardika

Selective breeding program in shrimp culture by focusing on finding and improving WSSV tolerance traits on the species is very important to develop better genotypic characters of black tiger shrimp spawners. The aim of the research was to determine genotype profile of shrimp fry produced from selective breeding and suspected to carry WSSV tolerance traits. The selection method was initiated from culturing and breeding of wild shrimp spawners (F-O) in which probiotics were applied and biosecurity and viral diseases diagnosis were tightly monitored. Challenge test to WSSV infection (LD-50) was carried out by submersion and oral feeding. The results showed that shrimp fry of F-1 phenotypically varied (big, regular and small size). F-1 shrimp fry 
screened from phenotypic selection with fast growth was $20.18 \%-35.04 \%$ of the total fry population, while regular and slow growth were $43.28 \%-70.49 \%$ and $9.47 \%-21.66 \%$ respectively. Genotypic performance of F-1 shrimp fry showed different genetic variations. Heterozigocity value of $\mathrm{F}-1$ shrimp fry with big size was 0.51 , while regular and small size were 0.45 and 0.22 , respectively. Mortality of small size shrimp fry on $L D-50$ test occurred after 48 hour post challenge test, while on regular and big size shrimp fry occurred after 72 hour. Genotype profile of shrimp fry tolerant to WSSV expressed more gene pattern variations.

\section{KEYWORDS: Penaeus monodon, selection, tolerance, WSSV infection}

\section{PENDAHULUAN}

Keterpurukan bisnis udang windu, Penaeus monodon di Indonesia oleh karena kegagalan budidaya, mengakibatkan volume ekspor udang tersebut juga mengalami penurunan sangat tajam. Walaupun demikian beberapa praktisi masih melakukan kegiatan budidaya secara tradisional (Jawa Timur, Kalimantan, Sulawesi Selatan), semi intensif (Kalimantan, Sulawesi Selatan) maupun intensif (Pulau Seram, Ambon). Bila ditelusuri, kegagalan budidaya udang windu banyak disebabkan oleh penurunan kualitas lingkungan, sehingga sangat rentan terhadap penyakit infeksi terutama virus (Gunarto et al., 2006). Menurut data FAO, estimasi produksi udang Indonesia pada tahun 2005 adalah 279.375 ton, sedangkan pada tahun 2007 sebanyak 234.000 ton dan pada tahun 2008 adalah 250.000 ton dengan perbandingan $70 \%$ udang vaname L. vannamei dan $30 \%$ udang windu. Sementara pada tahun 2007 berubah menjadi $80 \%$ udang vaname dan $20 \%$ udang windu, $P$. monodon (Permana et al., 2009).

Akibat penurunan kegiatan budidaya udang windu di tambak, maka kegiatan bisnis beralih pada budidaya udang vaname. Diketahui bahwa induk udang vaname diimpor dari USA dan merupakan udang hasil seleksi (selection breeding). Dengan keterbatasan karakter genetik pada udang tersebut, maka sulit untuk dikembangbiakkan dalam jangka panjang, sehingga ketergantungan impor sangat tinggi. Akibat lanjut dari akivitas tersebut devisa negara akan mengalir ke negara lain.

Dalam upaya mengembalikan kejayaan budidaya udang windu, maka langkah perbaikan dan antisipasi serta pencegahan terhadap faktor kegagalan terus dilakukan. Satu di antara upaya yang mendapatkan perhatian adalah penanganan terhadap karakter genetik udang windu. Diawali dengan pemetaan (mapping) keragaman genetik udang windu diperairan Indonesia (Benzie et al., 2002; Sugama et al., 2002), domestikasi induk udang dari perairan berbeda melalui pembenihan dan mengevaluasi benih turunannya (Moria et al., 2002; Moria et al., 2003), serta seleksi secara fenotip ataupun genotype pada udang windu (Haryanti et al., 2006; Haryanti \& Sugama, 2007).

Menurut Benzie et al. (1997), Hedgecock et al. (1982) dan Lester (1983) bahwa pengembangan metode domestikasi pada udang Penaeid dimaksudkan untuk mengantisipasi tekanan terhadap stok induk alam, sehingga telah direalisasikan perbaikan mutu udang melalui seleksi dengan memerlukan data variasi genetik yang tepat pada populasi induk. Hal ini mengingat bahwa perairan Indonesia mempunyai sumber keanekaragaman hayati laut terbesar di dunia, dan diperkirakan pada perairan tersebut juga mempunyai tingkat keragaman populasi udang yang secara genetik juga besar, dengan keunggulan fenotip (ukuran udang besar) dan genotip (heterozigositas tinggi) (Klinbunga et al., 1998; Duda \& Palumbi, 1999; Benzie, 2000).

Skala prioritas dalam pembenihan untuk target keberhasilan budidaya adalah perbaikan mutu induk dan benih udang windu melalui seleksi. Benih yang dihasilkan dari induk udang windu hasil seleksi diharapkan akan menghasilkan kualitas benih yang baik secara genotip maupun fenotip. Beberapa riset terhadap benih dan induk udang telah difokuskan melalui teknik seleksi dengan mengutamakan sifat- sifat yang menguntungkan bagi budidaya (tumbuh cepat, toleranresisten terhadap infeksi virus, reproduksi, dan lain- lain). Penggunaan penciri gen untuk karakter tersebut di atas dalam seleksi (Marker Assisted Selection/MAS) akan sangat bermanfaat. 
Dari beberapa hasil uji pendahuluan yang telah diperoleh dalam breeding pada udang windu yang bebas penyakit (Spesific Pathogen Free/ SPF) dengan pendeteksian terhadap 7 jenis infeksi virus, nampak bahwa calon induk udang turunan F- 1 yang bersifat SPF dengan metoda pemeliharaan yang mengaplikasikan biosecurity sebesar 85\% $90 \%$ Sementara, untuk induk udang windu yang berasal dari alam, sifat SPF tersebut menunjukkan angka yang relatif lebih kecil, oleh karena adanya infeksi virus selama penampungan di tempat pengumpul.

Riset seleksi melalui seleksi famili dengan mengutamakan karakter bebas penyakit serta toleran-resisten terhadap infeksi WSSV menjadi pilihan mendesak untuk mendapatkan calon induk udang windu dengan sifat fenotip dan genotip yang lebih baik. Program seleksi menjadi penting untuk mengetahui besaran korelasi genetik antara sifat-sifat yang diinginkan dalam rangka program seleksi dan mengontrol respons korelasi (Gitterle et al., $2005^{\mathrm{a}}$ ). Pada udang vaname, korelasi genetik antara sifat resisten terhadap TSV dan pertumbuhan tidak menguntungkan (Fjalestad et al., 1999; Argue et al., 2002). Namun Gitterle et al. (2005b) melaporkan bahwa ada keuntungan korelasi genetik antara laju pertumbuhan dan sintasan udang di tambak.

Tujuan riset ini adalah mendapatkan metode seleksi induk udang windu yang bersifat bebas penyakit dan toleran- resisten terhadap infeksi WSSV dengan teknik penanda genetik dalam upaya perbaikan mutu genetik agar diperoleh induk dan turunan yang berkualitas baik secara genotip serta fenotip. Keberhasilan upaya tersebut diharapkan dapat memotivasi praktisi untuk menggunakan udang windu sebagai spesies andalan dalam bisnis budidaya udang. Terobosan ini untuk mengantisipasi penurunan karakter genetik udang dan ketergantungan induk alam serta impor induk udang dari luar negeri. Ke depan, diharapkan dapat memberikan peluang industri pembenihan udang skala komersial untuk memasok kebutuhan benih bagi budidaya tambak.

\section{BAHAN DAN METODE}

\section{Profil Fenotip}

Langkah awal pelaksanaan riset dilakukan dengan penyediaan benih uji melalui pembenihan. Pembenihan menggunakan induk udang windu turunan F- 0 yang berasal dari perairan Aceh dengan rasio jantan : betina sebesar 1:1. Udang windu mempunyai ukuran panjang $26,60-31,70 \mathrm{~cm}$ dan bobot 164,70 $234,30 \mathrm{~g}$ pada induk betina. Sementara, pada induk jantan ukuran panjang dan bobot masing- masing sebesar 20,00-20,50 cm dan $59,80-68,60 \mathrm{~g}$. Semua aktivitas pembenihan mengacu pada penggunaan induk dengan kondisi SPF yang dilakukan melalui metoda deteksi bebas penyakit terhadap 7 jenis patogen virus yaitu: TSV, WSSV, IHHNV, YHV, BP, MBV, dan HPV. Analisis deteksi dengan IQ- 2000 kit. Semua hasil pengujian tersebut harus bersifat negatif terhadap semua infeksi jenis virus. Induk udang windu dipijahkan dengan perangsangan hormonal internal melalui ablasi tangkai mata. Induk udang windu diberikan pakan segar berupa cumi, cacing laut, dan kerang sebanyak $15 \%$ dari bobot total induk udang per hari. Larva udang windu dipelihara dengan pemberian pakan berupa Chaetoceros ceratosporum, Skeletonema costatum, Artemia sp., dan pakan buatan mikroencapsulasi. Kepadatan awal C. ceratosporum pada stadia awal larva sebanyak 5000- $20.000 \mathrm{sel} / \mathrm{mL}$, sedangkan pada stadia lanjut diberikan Skeletonema sp. (25.000$35.000 \mathrm{sel} / \mathrm{mL}$ ) dan Artemia sp. (5- 15 naupli/ larva). Sementara, dosis pakan buatan diberikan sesuai dengan petunjuk yang ada dalam kemasan. Pergantian air dimulai saat stadia zoea-3 hingga stadia postlarva dengan tingkat yang berbeda ( $15 \% 50 \%$ ). Penyediaan benih uji mengaplikasikan seleksi famili yang diperoleh melalui pemijahan induk betina secara terpisah. Benih F- 1 yang dihasilkan dari masing-masing induk udang windu betina tersebut dipelihara dan diseleksi dengan memilih karakter tumbuh cepat, sedang dan lambat, sehat, dan keragaan morfologi yang baik.

Tahap selanjutnya adalah melakukan uji tantang dengan virus WSSV terhadap benih udang yang mempunyai variabilitas pertumbuhan (besar, sedang, dan kecil). Pada tahapan tersebut udang diinfeksikan secara oral dan perendaman. Waktu uji dilakukan selama 96 jam. Penyediaan pakan dimulai dengan menularkan udang yang positif terinfeksi WSSV pada udang sehat secara kohabitasi. Udang yang sakit atau moribund (hampir mati) digunakan sebagai pakan pada benih udang windu yang diujikan secara oral. Sementara, infeksi melalui perendaman dilakukan dengan merendam benih udang uji 
dalam $30 \mathrm{~L}$ air laut yang telah diinfeksikan inokulan WSSV selama 2 jam. Setiap perlakuan (oral dan perendaman) dilakukan secara terpisah. Pengamatan mortalitas dilakukan dengan interval waktu setiap 24 jam pemaparan.

\section{Profil Genotip}

Pengujian karakter genotip dilakukan dengan mengekstraksi total DNA benih udang windu F- 1 ukuran besar, sedang, dan kecil mengikuti metode Ovenden (2000) dengan beberapa modifikasi. Purifikasi genome DNA dengan menggunakan Kit QIAquick Purification (Cat. No.28104 QIAGEN) dan metode mengikuti manual yang ada dalam kit (kemasan). Hasil purifikasi merupakan genom DNA yang murni dengan konsentrasi tinggi untuk amplifikasi PCR.

Amplifikasi DNA dengan speedy PCR dengan menggunakan kit Go taq polymerase (Promega). Primer yang digunakan adalah universal primer 2AAM2, AS- 15, AS- 14, dan LS- 21 dengan konsentrasi 25 pmol. Reaksi PCR dengan total volume $10 \mu \mathrm{L}$ digunakan $5 \mathrm{x}$ Buffer $(2,0 \mu \mathrm{L}) ; 0,2 \mu \mathrm{L}$ dNTP mix (10 mM); 1,5 $\mu \mathrm{L} \mathrm{MgCl}_{2}(25 \mathrm{mM}) ; 1,0 \mu \mathrm{L}$ Primer (25 pmol); 0,2 $\mu \mathrm{L}$ Taq polimerase; $\mathrm{H}_{2} \mathrm{O}$ sebanyak $4,1 \mu \mathrm{L}$ dan genom DNA: 1,0 $\mu \mathrm{L}(15-20 \mathrm{ng} / \mu \mathrm{L})$. Thermocycle PCR sebanyak 35 siklus, dengan awal denaturasi $95^{\circ} \mathrm{C}$ selama 120 detik, denaturasi dengan suhu $95^{\circ} \mathrm{C}$ (5 detik), annealing $55^{\circ} \mathrm{C}$ (10 detik) dan ekstensi $72^{\circ} \mathrm{C}$ (30 detik), sedangkan ekstensi akhir $72^{\circ} \mathrm{C}$ (120 detik). Lama amplifikasi PCR ini hanya memerlukan waktu sekitar 45 menit.

Selanjutnya analisis genotip menggunakan metode SSCP (Single Strand Conformation Polymorphism). Dalam analisis tersebut digunakan Gel polyacrilamid (Genegel Clean Excel 15/24) yang telah mengalami rehydration. Separasi hasil amplifikasi PCR dielektroforesis dengan Genphore yang telah dimediasi oleh $\mathrm{ddH}_{2} \mathrm{O}$ agar gel tidak melekat langsung pada chamber Genphore. Selanjutnya sampel uji dimasukkan ke dalam sumuran yang ada pada gel polyacrilamid sebanyak 6 uL. Arus listrik dialirkan dari negatip ke positip digunakan 2 lembaran blot paper yang berfungsi sebagai jembatan (bridge) buffer. Separasi gen dalam gel polyacrilamid dikondisikan pada suhu $15^{\circ} \mathrm{C}$ selama 45 menit.

Proses pewarnaan menggunakan kit metode silver staining, setiap tahap perendaman gel polyacrilamid harus digoyang (shaker) agar larutan dapat merendam seluruh permukaan gel. Tahapan pewarnaan meliputi fixing (90 menit), pewarnaan (staining) selama 30 menit, developing (8- 10 menit) dan penghentian proses pewarnaan (30 menit). Preservasi gel polyacrilamid dengan cara dikering-anginkan pada suhu ruang dengan posisi vertikal. Setelah gel polyacrilamid kering, dilakukan penghitungan dan pembacaan pita (fragmen) DNA yang terekspresi. Hasil pengamatan fenotip dan genotip dianalisis dengan menggunakan software genetic TFGPA (Tool for Genetic Population) serta analisa data secara deskriptif dan tabulasi.

\section{HASIL DAN BAHASAN}

\section{Performansi Fenotip}

Hasil pembenihan yang dilakukan menggunakan 35 pasang induk alam, berasal dari perairan Aceh (F-0), menunjukkan bahwa fekunditas telur dan laju penetasan telur (hatching rate/ HR) yang bervariasi. Setelah dilakukan ablasi pada induk betina, tidak semua induk udang betina memberikan respons kematangan gonad dan mengalami pemijahan serta menghasilkan fekunditas dan daya tetas telur yang tinggi. Seringkali induk udang tidak memijah dan gonad diserap kembali atau induk udang memijah secara parsial, jumlah telur sedikit, telur tidak dibuahi (infertil) atau telur tidak dapat berkembang sempurna untuk menetas menjadi larva. Dari induk yang ada, hanya 15 ekor yang memberikan respons kematangan gonad. Rata- rata fekunditas telur yang diperoleh antara $280,000-883,000$ butir dengan daya tetas telur berkisar 33,26\% 100\%

Namun, hingga akhir pembenihan ternyata hanya 5 famili yang dapat menghasilkan benih hingga dilakukan seleksi pertumbuhan. Pada udang Penaeid, fekunditas telur sangat dipengaruhi oleh nutrien, lingkungan dan proses hormonal pada badan udang. Induk udang dengan pemberian nutrien yang baik dan seimbang serta lingkungan yang memadai, dimungkinkan akan menghasilkan fekunditas telur yang tinggi. Sementara, daya tetas telur sangat dipengaruhi oleh proses perkembangan embrio dalam telur, ketersediaan energi untuk pembelahan.

Seleksi yang telah dilakukan terhadap sifat SPF pada udang windu turunan F- 0 melalui 
deteksi 7 virus (WSSV, TSV, YHV, BP, IHHNV, HPV, dan MBV) menunjukkan bahwa induk udang bersifat SPF. Hal ini membuktikan bahwa induk- induk F- 0 tidak terinfeksi virus hingga menghasilkan benih generasi pertama (F- 1$)$. Benih udang windu generasi pertama (F- 1 ) juga tidak terinfeksi virus (Tabel 1 ). Adanya variasi pertumbuhan pada benih F- 1 terutama udang yang berukuran kecil, nampaknya bukan infeksi IHHNV, tetapi disebabkan oleh faktor genetis. Walaupun, indikasi dari adanya infeksi IHHNV pada udang adalah kekerdilan atau pertumbuhan lambat. Menurut Rai et al. (2009) bahwa benih udang windu dari hatcheri menunjukkan insidensi relatif tinggi terinfeksi IHHNV yaitu $61,9 \%$ diikuti oleh infeksi MBV $(9,8 \%)$, HPV ( $8,4 \%)$, dan WSSV (2,8\%). Pada udang windu seringkali menunjukkan kondisi klinis yang dikenal sebagai monodon slow growth syndrome (MSGS)

Tabel 2 menunjukkan bahwa populasi udang stadia yuwana (60 hari) dengan pertumbuhan cepat sebesar $20,18 \%$ sedangkan udang dengan pertumbuhan lambat sebesar $9,47 \%$ dan udang dengan pertumbuhan sedang sebesar 70,49\% Dengan kenyataan populasi udang tumbuh cepat relatif rendah, maka seleksi yang dilakukan harus menghasilkan banyak famili sehingga jumlah individu udang berukuran besar dapat terkumpul lebih banyak. Dari hasil seleksi tahap pertama tersebut, maka pemeliharaan yuwana udang selalu dipantau karakter SPF dan pertumbuhannya serta dilakukan penandaan menggunakan VIE untuk mempermudah pemeliharaan. Seleksi fenotip berikutnya (120 hari), menunjukkan bahwa persentase ukuran besar semakin besar $(35,04 \%)$, sedangkan ukuran sedang/reguler hanya $43,28 \%$ dan udang ukuran kecil $21,66 \%$

Hasil pengamatan terhadap pertumbuhan udang windu F- 1 hasil seleksi menunjukkan bobot dan panjang rata- rata antara 9,1-25,4 g dan 9,6-15,6 cm untuk ukuran besar. Sementara, udang ukuran sedang diperoleh bobot dan panjang antara 4,8- 8,7 g dan 8,0$9,4 \mathrm{~cm}$. Hasil seleksi pada udang berukuran kecil hanya menunjukkan bobot 3,2-4,0 $\mathrm{g}$ dan panjang 4,2- 5,7 cm. Nampak bahwa calon induk udang windu F- 1 dari semua turunan induk betina (F-0) menunjukkan pertumbuhan yang pesat kecuali induk + 11 . Hal ini terlihat dari meratanya pertumbuhan pada saat pengamatan kedua untuk mengadakan seleksi. Udang

Tabel 1. Hasil analisis karakter SPF (Specific Pathogen Free) melalui deteksi tujuh jenis virus pada induk alam ( $\mathrm{F}-0$ ) dan benih generasi pertama ( $\mathrm{F}-1)$ udang windu, $P$. Monodon

Table 1. Analysis result of SPF (Specific Pathogen Free) traits through seven virus detection on shrimp spawners (F-O) and first generation fry of black tiger shrimp P. monodon

\begin{tabular}{|c|c|c|c|c|c|c|c|c|}
\hline \multirow{2}{*}{\multicolumn{2}{|c|}{$\begin{array}{l}\text { Sampel } \\
\text { Sample }\end{array}$}} & \multicolumn{7}{|c|}{ Deteksi virus (Virus detection) } \\
\hline & & BP & HPV & IHHNV & MBV & TSV & WSSV & YHV \\
\hline \multicolumn{9}{|c|}{ Induk (F-0) (Broodstock (F-0)) } \\
\hline o & -1 & - & - & - & - & - & - & - \\
\hline q & -2 & - & - & - & - & - & - & - \\
\hline q & -11 & - & - & - & - & - & - & - \\
\hline 우 & -20 & - & - & - & - & - & - & - \\
\hline 우 & -22 & - & - & - & - & - & - & - \\
\hline \multicolumn{9}{|c|}{ Benih generasi pertama F-1 (First generation fry F-1) } \\
\hline 우 & -1 & - & - & - & - & - & - & - \\
\hline 우 & -2 & - & - & - & - & - & - & - \\
\hline q & -11 & - & - & - & - & - & - & - \\
\hline 우 & -20 & - & - & - & - & - & - & - \\
\hline 우 & -22 & - & - & - & - & - & - & - \\
\hline
\end{tabular}

Keterangan/Remark: (- ) : negatif (tidak terinfeksi)/ negative (uninfected) 
Tabel 2. Hasil seleksi ukuran bobot dan panjang udang windu, P. monodon generasi pertama (F-1)

Table 2. The result of size selection (body weight and total length) of black tiger shrimp $\boldsymbol{P}$. monodon first generation ( $F-1)$

\begin{tabular}{|c|c|c|c|c|}
\hline $\begin{array}{l}\text { Induk } \\
\text { Spawner }\end{array}$ & $\begin{array}{c}\text { Ukuran besar } \\
\text { Big size } \\
\text { (ekor/ pcs) }\end{array}$ & $\begin{array}{c}\text { Ukuran sedang } \\
\text { Regular size } \\
\text { (ekor/ pcs) }\end{array}$ & $\begin{array}{l}\text { Ukuran kecil } \\
\text { Small size } \\
\text { (ekor/pcs) }\end{array}$ & $\begin{array}{c}\text { Jumlah udang } \\
\text { Total number } \\
\text { (ekor/ pcs) }\end{array}$ \\
\hline \multirow[t]{2}{*}{ B-1 } & 418 & 589 & 31 & 1,038 \\
\hline & $(40.27 \%$ & $(56.74 \%)$ & $(2.99 \%)$ & \\
\hline \multirow[t]{2}{*}{ B-2 } & 99 & 1675 & 231 & 2,005 \\
\hline & $(4.94 \%)$ & $(83.54 \%)$ & $(11.52 \%$ & \\
\hline \multirow[t]{2}{*}{ B-11 } & 687 & 2069 & 92 & 2,848 \\
\hline & $(24.12 \%)$ & (72.65\%) & $(3.23 \%)$ & \\
\hline \multirow[t]{2}{*}{ B-20 } & 588 & 1985 & 295 & 2,846 \\
\hline & $(20.66 \%)$ & $(69.75 \%$ & $(10.36 \%)$ & \\
\hline \multirow[t]{2}{*}{ B-22 } & 564 & 3,600 & 994 & 5,158 \\
\hline & $(10.93 \%)$ & $(69.79 \%$ & $(19.27 \%$ & \\
\hline Rata-rata (Average) & $20.18 \%$ & $70.49 \%$ & $9.47 \%$ & \\
\hline Bobot (Weight) (g) & $0.38-0.99$ & $0.12-0.20$ & $0.03-0.11$ & \\
\hline Panjang (Length) (cm) & $0.41-0.66$ & $0.7-0.43$ & $0.11-0.46$ & \\
\hline
\end{tabular}

Total

13,895

dengan ukuran besar, sedang, dan kecil mempunyai laju pertumbuhan yang relatif sama.

Hasil uji tantang virus WSSV terhadap udang windu F- 1 yang tumbuh cepat, sedang dan lambat menunjukkan hasil yg relatif berbeda, seperti tertera pada Tabel 3. Uji tantang virus WSSV melalui oral memberikan efek mortalitas yang lebih tinggi dari pada perendaman. Pada pemaparan 72 jam, benih ukuran besar mengalami mortalitas 12\% $80 \%$ sedangkan mortalitas benih ukuran sedang dan kecil masing- masing sebanyak $42 \% 82 \%$ dan $28 \%$ 72\% Hanya benih udang dari turunan induk 9 - 20 mortalitas tinggi pada infeksi oral terlihat pada pemaparan 96 jam. Sementara, pada perendaman hampir semua benih udang ukuran besar, sedang, dan kecil mengalami mortalitas pada pemaparan WSSV selama 96 jam, walaupun juga diperoleh benih udang yang bertahan hidup hingga akhir waktu pemaparan secara oral. Hal ini diduga dengan jumlah copy virion DNA virus dalam tubuh benih udang yang dapat ditoleransi secara individual, sehingga infeksi WSSV hanya bersifat latent. Di samping itu, diduga benih udang hasil seleksi ada yang mempunyai gen pengontrol terhadap toleransi terhadap WSSV. Menurut Silverstein (2005), bahwa dalam populasi ikan yang diinfeksikan dengan jenis penyakit tertentu yang mematikan, maka akan ada beberapa individu yang bertahan hidup. Bila dilakukan analisis molekuler (AFLP/ microsatelit) maka terekspresi gen tertentu pengontrol ketahanan terhadap infeksi penyakit.

Keberhasilan pemeliharaan spesies udang akan langsung berhubungan dengan potensinya beradaptasi terhadap lingkungan. Demikian pula adanya spesifik patogen dapat juga menginfeksi semua populasi bila terjadi homogenitas genetik pada kondisi yang memadai, sehingga dapat terjadi tidak ada individu yang resisten terhadap penyakit.

Hasil diagnosis terhadap benih F- 1 ukuran besar, sedang, dan kecil yang telah mengalami uji tantang, baik secara oral maupun perendaman dengan menggunakan metode IQ 2000 kit, menunjukkan hasil yang negatif terhadap infeksi WSSV. Namun, setelah dilakukan diagnosis menggunakan kit dengan spesifik primer WSSV (panjang fragmen 113 bp), menunjukkan hasil yang berbeda yaitu 


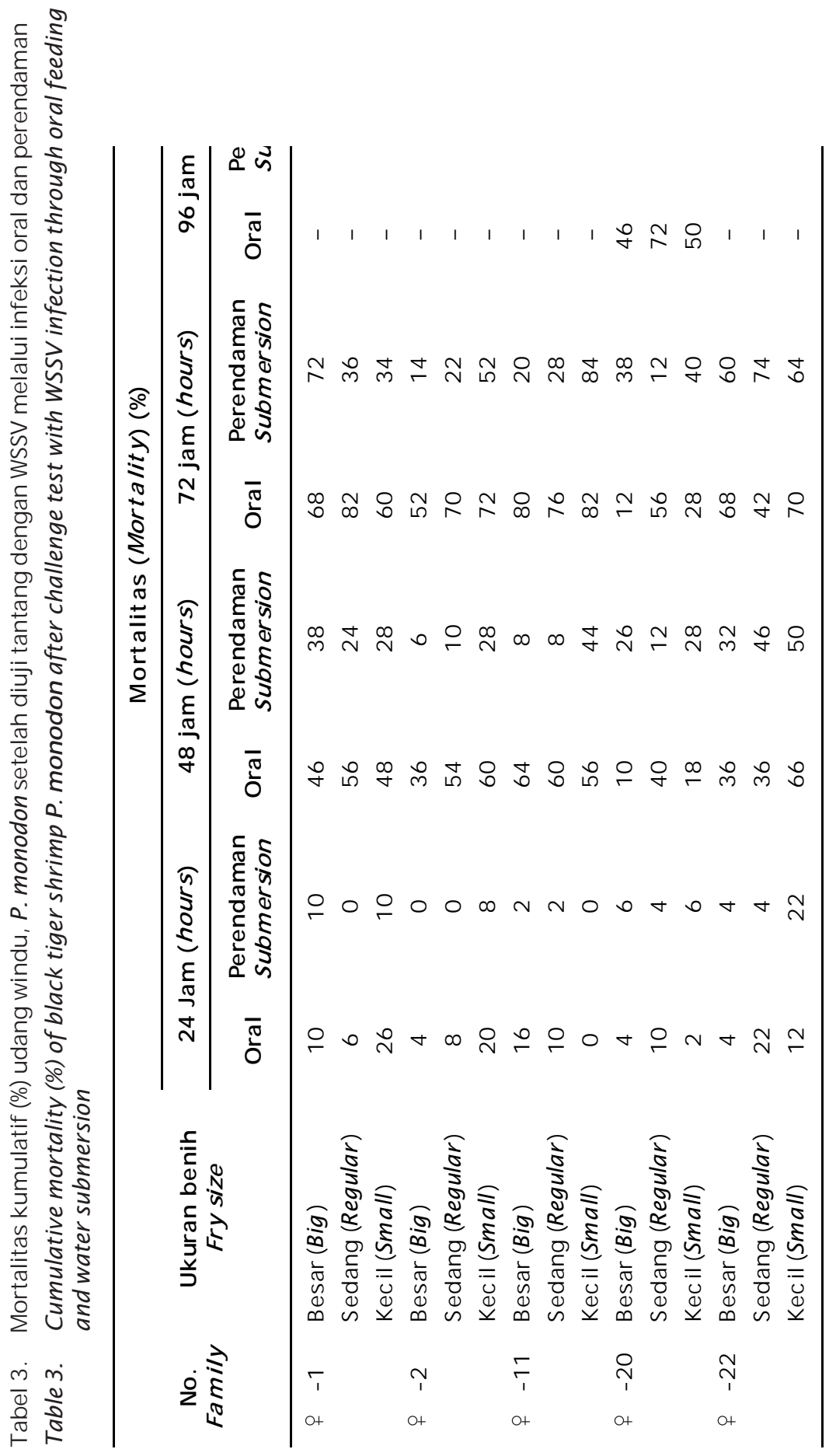


semua sampel udang positif terinfeksi WSSV. Nampaknya, sensitivitas pengujian sangat menentukan untuk uji selanjutnya. Terlihat bahwa ada asumsi bahwa benih udang turunan F- 1 yang hidup setelah di uji tantang WSSV pada waktu tertentu (96 jam) mengindikasikan adanya sifat toleran atau carrier atau latent terhadap infeksi WSSV (Gambar 1).

\section{Performansi Genotip}

Hasil analisis DNA pada udang windu F- 1 melalui amplifikasi dengan Speedy PCR dan separasi DNA menggunakan metode SSCP (Single Strand Conformation Polymorphism) menunjukkan perbedaan polimorfisme fragmen DNA pada benih tumbuh cepat, regular, dan lambat (Tabel 4). Genotip benih udang F- 1 dari turunan 5 ekor induk betina relatif beragam dengan nilai heterozigositas antara 0,23-0,79 (ukuran besar), 0,32-0,64 (ukuran sedang) dan 0-0,39 (ukuran kecil). Menurut
Sbordoni et al. (1987), bahwa variasi genetik sangat penting untuk kelanjutan produktivitas stok kultur pada udang penaeid ( $P$. japonicus). Hal ini ditunjukkan oleh hubungan yang erat antara penurunan produktivitas induk dengan variabilitas pertumbuhan.

Nampak dari hasil perhitungan heterozigositas, bahwa udang windu F- 1 dengan pertumbuhan cepat mempunyai nilai yang relatif lebih tinggi (rata- rata 0,51 ), tidak berbeda nyata dengan benih $\mathrm{F}-1$ ukuran sedang $(0,45)$ sedangkan benih ukuran kecil sebesar 0,22. Nilai heterosigositas generasi pertama tumbuh cepat tidak berbeda nyata dengan induk F- 0 jantan $(0,6091)$ dan betina $(0,2872)$ (Haryanti et al., 2009). Hal ini dimungkinkan adanya segregasi gen pada turunan F- 1 yang terekspresi secara jelas dalam benih tersebut. Selain itu, mengingat adanya perkawinan udang dalam kondisi random mating dan massal, sehingga peluang terjadinya mating

A

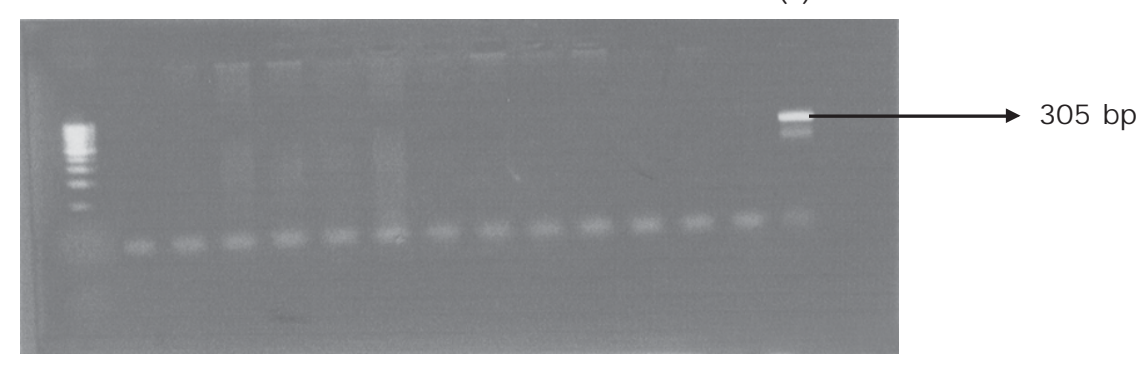

$\begin{array}{lllllllllllllllll}M & 1 & 2 & 3 & 4 & 5 & 6 & 7 & 8 & 9 & 10 & 11 & 12 & 13 & 1415 & 16 & M\end{array}$

B

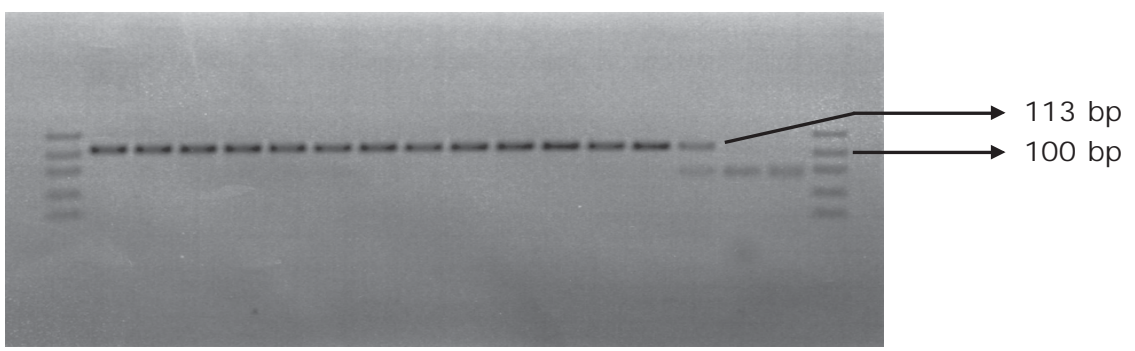

Gambar 1. Pola amplifikasi PCR untuk diagnosis infeksi WSSV pada benih F- 1 udang windu, P. monodon. (A): amplifikasi PCR dengan metoda IQ- 2000, (B): amplifikasi PCR dengan spesifik primer 113 bp. 1 - 13 : udang uji, 14 : kontrol positif, 15- 16 : kontrol negatif, M : Marker Ultra low range DNA ladder

Figure 1. PCR amplication pattern to diagnose WSSV infection on the black tiger shrimp P. monodon first generation (F-1) fry. (A) PCR amplification by using IQ-2000 method, (B) PCR amplification by using spesific primer of 113 bp. 1-13 : shrimp sample, 14 :positive control, 15-16: negative control, $M$ : Marker Ultra low range DNA ladder 
Tabel 4. Genotip dan allel frekuensi pada lokus yang terdeteksi pada F- 1 udang windu, $P$. monodon hasil seleksi famili

Table 4. Genotype and allel frequencies on detected loci of P. monodon first generation (F-1) fry produced from family selection

\begin{tabular}{|c|c|c|c|c|c|c|c|c|}
\hline \multirow{2}{*}{$\begin{array}{c}\text { Generasi udang } \\
\text { Shrimp } \\
\text { generation }\end{array}$} & \multirow{2}{*}{$\mathbf{N}$} & \multirow{2}{*}{$\begin{array}{l}\text { Genotip } \\
\text { Genotype }\end{array}$} & \multicolumn{5}{|c|}{ Allel frequencies } & \multirow{2}{*}{$\begin{array}{c}\text { Heterozigositas } \\
\text { Heterozigosity }\end{array}$} \\
\hline & & & A & B & C & D & E & \\
\hline \multicolumn{9}{|l|}{ F-1 $q$ - 1} \\
\hline \multirow[t]{2}{*}{ Besar (Big) } & 13 & $A$ & 0.87 & 0.00 & 0.00 & 0.00 & 0.00 & 0.23 \\
\hline & 2 & $B$ & 0.00 & 0.13 & 0.00 & 0.00 & 0.00 & \\
\hline \multirow[t]{2}{*}{ Sedang (Regular) } & 12 & $A$ & 0.80 & 0.00 & 0.00 & 0.00 & 0.00 & 0.32 \\
\hline & 3 & $B$ & 0.00 & 0.20 & 0.00 & 0.00 & 0.00 & \\
\hline Kecil (Small) & 15 & $A$ & 0.00 & 0.00 & 0.00 & 0.00 & 0.00 & 0.00 \\
\hline \multicolumn{9}{|l|}{ F-1 우 - 2} \\
\hline \multirow[t]{3}{*}{ Besar (Big) } & 3 & A & 0.20 & 0.00 & 0.00 & 0.00 & 0.00 & 0.50 \\
\hline & 10 & $B$ & 0.00 & 0.67 & 0.00 & 0.00 & 0.00 & \\
\hline & 2 & $\mathrm{C}$ & 0.00 & 0.00 & 0.13 & 0.00 & 0.00 & \\
\hline \multirow{2}{*}{ Sedang (Regular) } & 12 & $A$ & 0.80 & 0.00 & 0.00 & 0.00 & 0.00 & 0.32 \\
\hline & 3 & $B$ & 0.00 & 0.20 & 0.00 & 0.00 & 0.00 & \\
\hline \multirow[t]{2}{*}{ Kecil (Small) } & 11 & $A$ & 0.73 & 0.00 & 0.00 & 0.00 & 0.00 & 0.39 \\
\hline & 4 & B & 0.00 & 0.27 & 0.00 & 0.00 & 0.00 & \\
\hline \multicolumn{9}{|l|}{ F-1 우 - 11} \\
\hline \multirow[t]{5}{*}{ Besar (Big) } & 2 & $A$ & 0.14 & 0.00 & 0.00 & 0.00 & 0.00 & \\
\hline & 3 & $B$ & 0.00 & 0.21 & 0.00 & 0.00 & 0.00 & 0.79 \\
\hline & 2 & $\mathrm{C}$ & 0.00 & 0.00 & 0.14 & 0.00 & 0.00 & \\
\hline & 3 & $\mathrm{D}$ & 0.00 & 0.00 & 0.00 & 0.21 & 0.00 & \\
\hline & 4 & $E$ & 0.00 & 0.00 & 0.00 & 0.00 & 0.29 & \\
\hline \multirow[t]{3}{*}{ Sedang (Regular) } & 7 & $A$ & 0.47 & 0.00 & 0.00 & 0.00 & 0.00 & \\
\hline & 4 & B & 0.00 & 0.27 & 0.00 & 0.00 & 0.00 & 0.64 \\
\hline & 4 & $\mathrm{C}$ & 0.00 & 0.00 & 0.27 & 0.00 & 0.00 & \\
\hline \multirow[t]{3}{*}{ Kecil (Small) } & 9 & $A$ & 0.64 & 0.00 & 0.00 & 0.00 & 0.00 & \\
\hline & 1 & $\mathrm{~B}$ & 0.00 & 0.07 & 0.00 & 0.00 & 0.00 & 0.50 \\
\hline & 4 & C & 0.00 & 0.00 & 0.29 & 0.00 & 0.00 & \\
\hline \multicolumn{9}{|l|}{ F-1 $ㅇ-20$} \\
\hline \multirow[t]{3}{*}{ Besar (Big) } & 9 & $A$ & 0.60 & 0.00 & 0.00 & 0.00 & 0.00 & 0.52 \\
\hline & 5 & $B$ & 0.00 & 0.33 & 0.00 & 0.00 & 0.00 & \\
\hline & 1 & $\mathrm{C}$ & 0.00 & 0.00 & 0.07 & 0.00 & 0.00 & \\
\hline \multirow[t]{2}{*}{ Sedang (Regular) } & 11 & $A$ & 0.73 & 0.00 & 0.00 & 0.00 & 0.00 & 0.39 \\
\hline & 4 & B & 0.00 & 0.27 & 0.00 & 0.00 & 0.00 & \\
\hline \multirow[t]{2}{*}{ Kecil (Small) } & 13 & $A$ & 0.87 & 0.00 & 0.00 & 0.00 & 0.00 & 0.23 \\
\hline & 2 & $B$ & 0.00 & 0.13 & 0.00 & 0.00 & 0.00 & \\
\hline \multicolumn{9}{|l|}{ F-1우 - 22} \\
\hline Besar (Big) & 7 & $A$ & 0.47 & 0.00 & 0.00 & 0.00 & 0.00 & 0.50 \\
\hline & 8 & $B$ & 0.00 & 0.53 & 0.00 & 0.00 & 0.00 & \\
\hline Sedang (Regular) & 2 & $A$ & 0.13 & 0.00 & 0.00 & 0.00 & 0.00 & \\
\hline & 8 & B & 0.00 & 0.53 & 0.00 & 0.00 & 0.00 & 0.59 \\
\hline & 5 & $\mathrm{C}$ & 0.00 & 0.00 & 0.33 & 0.00 & 0.00 & \\
\hline Kecil (Small) & 15 & $B$ & 0.00 & 0.00 & 0.00 & 0.00 & 0.00 & 0.00 \\
\hline Rerata (Average) & & & & & & & & \\
\hline Besar (Big) & & & & & & & & 0.51 \\
\hline Sedang (Regular) & & & & & & & & 0.45 \\
\hline Kecil (Small) & & & & & & & & 0.22 \\
\hline
\end{tabular}


antara jantan dan betina dengan genotip berbeda sangat besar, akibatnya akan menghasilkan turunan yang mempunyai heterosigositas lebih bervariasi. Dengan demikian akan terjadi benih turunan generasi pertama F- 1 yang mempunyai keragaman genetik lebih baik atau menyerupai induk udang $\mathrm{F}-0$.

Dari Tabel 4 terlihat bahwa heterozigositas benih F- 1 tumbuh cepat, regular, dan lambat nampak berbeda nyata. Hal ini dapat dimengerti bahwa kemungkinan ada aliran gen yang dominan dari F- 0 jantan dan betina, mengingat induk tersebut mempunyai heterozigositas yang tinggi. Namun demikian, genotip induk udang betina (F-0) dan benih F- 1 yang tumbuh cepat lebih variatif dibandingkan induk jantan (F- 0) dan benih F- 1 tumbuh regular, sementara benih tumbuh lambat mempunyai polimorfisme lebih baik..

Bila heterozigositas dihitung dari benih udang windu F- 1 setiap famili, maka nampak bahwa benih udang ukuran kecil dari induk ㅇ- 2 dan ㅇ- 22 memberikan homogenitas. Sementara, benih F- 1 yang berasal dari \&- 11, mempunyai heterozigositas yang paling tinggi, baik untuk benih ukuran besar $(0,7857)$, sedang $(0,64)$, dan kecil $(0,50)$. Dari perhitungan tersebut menunjukkan bahwa benih udang windu ukuran besar dan sedang tidak menunjukkan perbedaan variasi genetik bila dilihat dari nilai heterozigositasnya.

Hasil analisis RAPD- fingerprint dengan menggunakan beberapa random primer (2AAM2, AS- 15, LS- 21, dan AS- 14) ternyata primer 2AAM2 menunjukkan signifikansi polimorfisme yang tinggi. Dengan menggunakan primer tersebut maka polimorfisme pada benih udang hasil uji tantang WSSV dapat diketahui. Pada lokus 2AAM2, nampak bahwa heterozigositas benih F- 1 ukuran besar dan hidup menunjukkan nilai lebih tinggi $(0,6667)$ dibandingkan dengan benih yang mati $(0,3030)$. Pada benih F- 1 ukuran sedang dan tetap hidup setelah uji tantang WSSV, heterozigositas sebesar 0,48 , sedangkan yang mengalami kematian hanya 0,30. Nilai heterozigositas pada benih F- 1 ukuran kecil menunjukkan hasil yang sama dengan benih ukuran sedang (Tabel 5). Hal ini nampaknya ada kemungkinan bahwa benih udang windu ukuran besar, selain mempunyai gen pengontrol tumbuh cepat, juga mengandung gen pengontrol toleransi- resisten terhadap WSSV.
Pada udang dengan beberapa ukuran (besar, sedang, dan kecil) dan tetap hidup setelah diinfeksi WSSV, nampak menunjukkan beberapa gen yang berbeda dibandingkan dengan udang uji yang mengalami mortalitas oleh karena terinfeksi WSSV (Gambar 5). Ekspresi ini dimungkinkan dapat dijadikan penciri gen untuk sifat toleransi. Beberapa penelitian yang berhubungan dengan penciri gen untuk karakter resisten WSSV banyak dilakukan dengan DNA marker mikrosatelit (Mukherjee \& Mandal, 2009; Dong et al., 2008) dengan menunjukkan DNA fingerprint $P$. monodon pada pita 317 bp untuk resisten WSSV, sedangkan udang yang rentan terhadap WSSV ada 2 pita yaitu 317 dan 71 bp.

\section{KESIMPULAN}

1. Benih udang windu F- 1 hasil seleksi pertumbuhan cepat sebesar 20,18 \% (I), $35.04 \%$ (II), sedangkan pertumbuhan sedang/ regular dan lambat masing- masing sebesar 70,49\%(I) 43,28\%(II) dan 9,47\%(I) $21,66 \%$ (II) dari populasi benih udang yang dihasilkan.

2. Sifat genotip udang windu F- 1 menunjukkan keragaman genetik yang berbeda. Nilai heterozigositas rata- rata pada benih udang windu F- 1 dengan tumbuh cepat sebesar 0,51 , sedangkan tumbuh sedang dan lambat masing- masing 0,45 dan 0,22.

3. Hasil uji tantang terhadap WSSV dengan perendaman maupun pemberian pakan menunjukkan adanya perbedaan toleransi pada benih udang windu F- 1 .

4. Nilai heterozigositas benih udang windu setelah uji tantang dengan WSSV menunjukkan bahwa pada benih udang F- 1 berukuran besar, sedang, dan kecil tetapi masih hidup, masing- masing dengan nilai sebesar 0,$61 ; 0,44$ dan 0,44 , sedangkan pada semua ukuran benih udang (besar, sedang, dan kecil) tetapi mengalami mortalitas, nilai heterozigositasnya hanya sebesar 0,28.

\section{UCAPAN TERIMA KASIH}

Diucapkan terima kasih pada Prof. Dr. Hanspeter Saluz dan Grit Mrozek, Hans Knoll Institute Germany, atas kerjasamanya. Kepada rekan-rekan teknisi litkayasa kelompok Bioteknologi BBRPBL Gondol, diucapkan terima kasih sebesar-besarnya atas bantuan yang penuh tanggung jawab sehingga riset ini dapat terlaksana dengan baik. 
Tabel 5. Genotip dan allel frekuensi pada lokus yang terdeteksi pada generasi pertama (F- 1) udang windu, P. monodon setelah uji tantang dengan WSSV

Table 5. Genotype and allel frequencies on detected loci of $\boldsymbol{P}$. monodon first generation (F-1) fry after WSSV challenge test

\begin{tabular}{|c|c|c|c|c|c|c|c|}
\hline \multirow{2}{*}{$\begin{array}{l}\text { Performansi benih F-1 } \\
\text { Performance of F-1 fry }\end{array}$} & \multirow{2}{*}{$\mathbf{N}$} & \multirow{2}{*}{$\begin{array}{l}\text { Genotip } \\
\text { Genetype }\end{array}$} & \multicolumn{4}{|c|}{ Al/el frequencies } & \multirow{2}{*}{$\begin{array}{l}\text { Heterozygositas } \\
\text { Heterozygocity }\end{array}$} \\
\hline & & & $\mathbf{A}$ & B & C & D & \\
\hline Ukuran besar-hidup & 4 & $\mathrm{~B}$ & 0.00 & 0.33 & 0.00 & 0.00 & \\
\hline \multirow[t]{2}{*}{ Big size-survive } & 6 & C & 0.00 & 0.00 & 0.50 & 0.00 & 0.61 \\
\hline & 2 & $\mathrm{D}$ & 0.00 & 0.00 & 0.00 & 0.17 & \\
\hline Ukuran besar-mati & 10 & $A$ & 0.83 & 0.00 & 0.00 & 0.00 & 0.28 \\
\hline Big size-death & 2 & B & 0.00 & 0.17 & 0.00 & 0.00 & \\
\hline Ukuran sedang-hidup & 8 & B & 0.00 & 0.67 & 0.00 & 0.00 & 0.44 \\
\hline Regular size-survive & 4 & C & 0.00 & 0.00 & 0.33 & 0.00 & \\
\hline Ukuran sedang-mati & 2 & $A$ & 0.17 & 0.00 & 0.00 & 0.00 & 0.28 \\
\hline Regular size-death & 10 & B & 0.00 & 0.83 & 0.00 & 0.00 & \\
\hline Ukuran kecil-hidup & 8 & B & 0.00 & 0.67 & 0.00 & 0.00 & 0.44 \\
\hline Small size-survive & 4 & $\mathrm{C}$ & 0.00 & 0.00 & 0.33 & 0.00 & \\
\hline Ukuran kecil-mati & 10 & $A$ & 0.83 & 0.00 & 0.00 & 0.00 & 0.28 \\
\hline Small size-death & 2 & B & 0.00 & 0.17 & 0.00 & 0.00 & \\
\hline
\end{tabular}

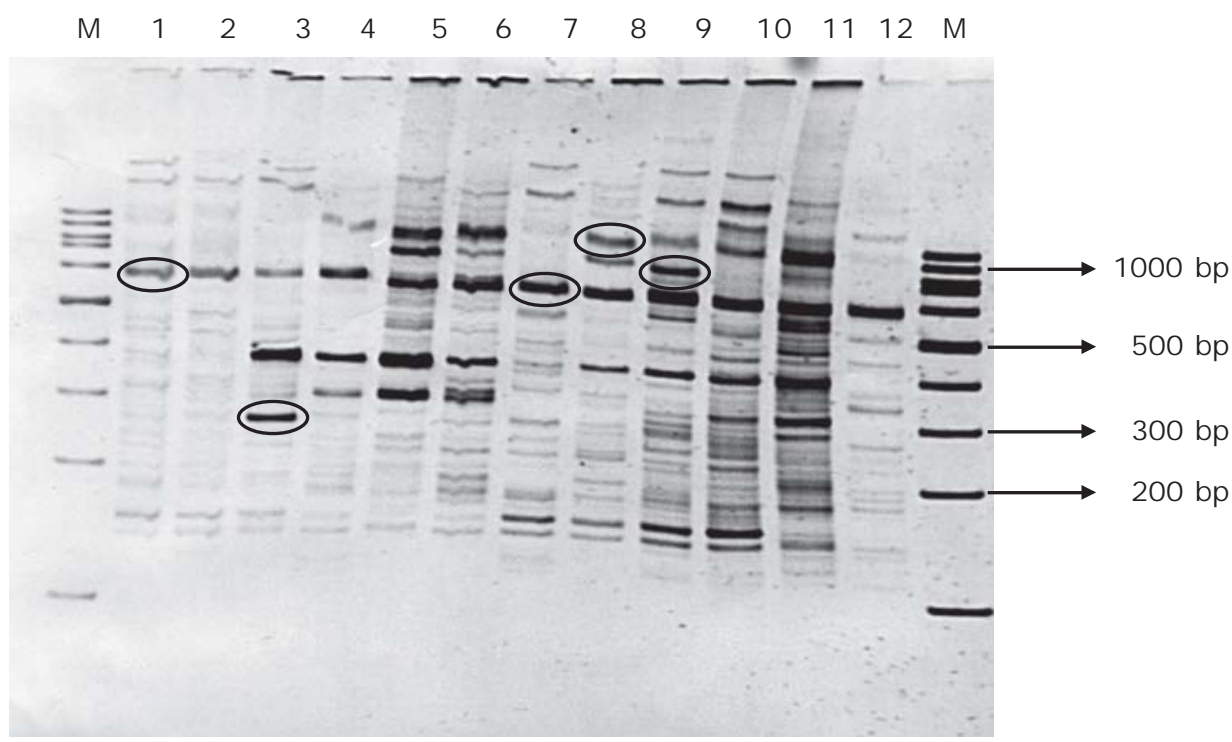

Gambar 2. Fingerprint- RAPD pada benih (F-1) udang windu, P. monodon hasil uji tantang dengan WSSV (1, 2, 3 dan 7, 8, 9: udang terinfeksi WSSV dan hidup, 4, 5, 6 dan 10, 11, 12 : udang terinfeksi WSSV dan mati, M: Maker DNA ladder $100 \mathrm{bp}$ )

Figure 2. RAPD-Fingerprint on first generation ( $F-1)$ shrimp fry, $P$. monodon, after challenge test with WSSV $(1,2,3$ and $7,8,9$ : infected shrimp and survive; 4 , 5, and 10,11,12: infected shrimp and dead; M: Maker DNA ladder $100 \mathrm{bp}$ ) 


\section{DAFTAR ACUAN}

Argue, B.J., Arce, M., Lotz, J.M., \& Moss, S.M. 2002. Selective breeding of Pacific white shrimp (Litopenaeus vannamei) for growth and resistance to Taura Syndrome Virus. Aquaculture, 204: 447- 460.

Benzie, J.A.H. 2000. Population genetic structure of Penaeid prawns. Aquaculture Res., 31: 95- 119.

Benzie, J.A.H., Ballment, E., Forbes, A.T., Dementriades, N.T., Sugama, K., Haryanti, \&Moria, S.B. 2002. Mt DNA variation in IndoPacific populations of the giant tiger prawn, Penaeus monodon. Molecular Ecology, 11: 2553- 2569.

Benzie, J.A.H., Kenway, M., \&Trott, L. 1997. Estimates for The Heritability of Size in Yuwanae P. monodon from Half-sib Mattings. Aquaculture, 152: 49- 53.

Dong, S., Kong, J., Meng, X., Zhang, Q., Zhang, T., \& Wang, R. 2008. Microsatellite DNA markers associated with resistance to WSSV in Penaeus (Fenneropenaeus) chinensis. Aquaculture, 282: 138- 141.

DudaJr., T.F., \& Palumbi, S.R. 1999. Population structure of the black tiger prawn, Penaeus monodon among Western Indian Ocean and Western Pacific populations. Mar. Biol., 134: 705- 710.

Fjalestad, K.T., Can, W.C., Lotz, J., Sweeney, J.N., \& Gjedrem, T. 1999. Genetic variation and selection response in body weight and disease resistance in Pacific white shrimp (Penaus vannamei). Aquaculture, 173: 1019.

Gitterle, T., Rye, M., Salte, R., Cock, J., Johansen, H., Suarez, J.A., Lozano, C., \& Gjerde, B. $2005^{\text {a }}$. Genetic (Co) variation in harvest body weight and survival in Penaeus (Litopenaeus) vannamei under standard commercial conditions. Aquaculture, 243: 83- 92.

Gitterle, T., Salte, R., Gjerde, B., Cock, J., Johansen, H., Salazar, M., Lozano, C., \& Rye. M. 2005 ${ }^{\text {b }}$. Genetic (co) variation in resistance to White Spot Syndrome Virus (WSSV) and harvest weight in Penaeus (Litopenaeus) vannamei. Aquaculture, 246: 139- 149.

Gunarto, Muslimin, Muliani, \& Sahabuddin. 2006. Analisis Kejadian Serangan White Spot Syndrome Virus (WSSV) dengan Beberapa Parameter Kualitas Air pada Budidaya Udang Windu Menggunakan
Sistem Tandon dan Probiotik. J. Ris. Akuakultur, 1(2): 255- 270.

Haryanti \&Sugama. 2007. Perbaikan mutu dan genetika udang. Kumpulan makalah Bidang Riset Perikanan Budidaya. Simposium Kelautan dan Perikanan Hotel Bidakara Jakarta, 7 Agustus 2007, $8 \mathrm{hlm}$.

Haryanti, Permana, I.G.N., Wardana, I.K., Muzaki, A., \& Fachrudin. 2006. Selektif breeding SPF (Specifik Pathogen Free) untuk udang windu, Penaeus monodon F- 1.11 hal. Laporan Teknis Balai Besar Riset Perikanan Budidaya Laut, Gondol, 11 hlm.

Haryanti, Muzaki, A., Wardana, I.K., Fachrudin, Sari Budi Moria, \& Permana, I.G.N. 2009. Phenotypic and Genotypic Performance of Black Tiger Shrimp Penaeus monodon having Fast Growth Traits. Indonesian Aquaculture Journal, 4(2) : 101- 108.

Hedgecock, D., Tracey, M.L., \& Nelson, K. 1982. The Biology of Crustacea. Vol. 2. Embryology, Morphology and Genetic. Academic Press, New York, p. 283- 402.

Klinbunga, S., Penman, D.J., Mc Andrew, B.J., Tassanakajon, A., \&Jarayabhand, P. 1998. Genetic variation, population differentiation, and gen flow of the giant tiger shrimp (Penaeus monodon) inferred from mtDNARFLP data. In Flegel, TW. (Ed.), Advances in Shrimp Biotechnology. National Center for Genetic Engineering and Biotechnology, Bangkok, p. 51- 59.

Lester, L.J. 1983. Developing a selective breeding program for Penaeid shrimp mariculture. Aquaculture, 33: 41- 50.

Moria, S.B., Haryanti, Permana, I. G.N., \& Sugama, K. 2002. Markah Genetik untuk Variabilitas Pertumbuhan Udang Windu, Penaeus monodon Dari Sumber Induk Berbeda Melalui Analisis mt- DNA RFLP. J. Penelitian Perikanan Indonesia, 8(5): 1- 9.

Moria, S.B., Permana, I.G.N., \& Haryanti. 2003. Analisis mt- DNA Dari Benih Asal Induk Udang Windu, Penaeus monodon Dari Perairan yang Berbeda. Aquaculture Indonesia, 4(1): 19- 27.

Mukherjee, K., \& Mandal, N. 2009. A Microsatellite DNA Marker Development for Identifying Diseases- resistent Population of Giant Black Tiger Shrimp, Penaeus monodon. Journal of the World Aquaculture Society, 40(2): 274- 280.

Ovenden, J. 2000. Development of restriction enzyme markers for red snapper (Lutjanus 
erythropterus and Lutjanus malabaricus) stock discrimination using genetic variation in mitochondria DNA. Molecular Fisheries Laboratory, Southern Fisheries Centre, $20 \mathrm{pp}$.

Permana. 2009. Analisis sifat toleran udang Litopenaeus vannamei terhadap infeksi Taura Syndrome Virus (TSV). Thesis Magister Program Pasca Sarjana, Universitas Brawijaya, Malang , $65 \mathrm{hlm}$.

Rai, P., Pradeep, B., Karunasagar, I., \& Karunasagar, I. 2009. Detection of viruses in Penaeus monodon from India showing signs of slow growth syndrome. Aquaculture, 289: 231- 235.
Sbordoni, V., De- Mattthaeis, E., CobolliSbordoni, M., La- Rosa, G., \& Mattoccia, M. 1987. Bottleneck Effects and The Depression of Genetic Variability in Hatchery Stocks of Penaeus japonicus (Crustacea: Decapoda). Aquaculture, 57: 239- 251.

Silverstein, J.T. 2005. Genetic improvement aquaculture. Global Aquaculture Advocate. 6(1): 50- 53.

Sugama, K., Haryanti, Benzie, J.A.H., \& Ballment, E. 2002. Genetic variation and population of the giant tiger prawn, Penaeus monodon, in Indonesia. Aquaculture, 205: 37- 48. 